\title{
Curriculum Content Improvement Needs for Accounting Employability Skills Acquisition of Undergraduate Students in North- East, Nigeria
}

\author{
Victoria Amelia Enemali \\ Department of Vocational and Technology Education, Faculty of Technology Education, Abubakar Tafawa \\ Balewa University, P. M. B 0248 Bauchi
}

\begin{abstract}
The study examined the curriculum content improvement needs for Accounting employability skills acquisition of undergraduate Accounting Education students in North-east, Nigeria. The study had two research questions and two null hypotheses. Descriptive survey research design was adopted for the study. The population of the study comprised 172 Accountants, 52 Accounting Educators and 312 final year undergraduate Accounting Education students. The sample of the study comprised 156 Accounting Educators, 52 Accountants in industries, and 281 final year undergraduate Accounting Education students. Structured questionnaire was used for data collection. The questionnaire had two different rating scales. The first rating scale was used to collect data relating to the level of importance of the skills to the needs of undergraduate Accounting Education students and the second rating scale was used to collect data on the extent to which the skills were consciously developed among the students. The structured questionnaire was validated and pilot tested, a reliability coefficient of 0.79 was obtained. The data were collected by the researcher assisted by 10 trained research assistants. The data were analyzed using Table of frequencies, mean scores, standard deviations, and improvement needs index to answer the research questions, while the hypotheses were tested using independent sample t. test. The study disclosed that 1 . All the skills were adjudged by Accounting Educators and Accountants in industries as very important for inclusion in the curriculum of undergraduate Accounting Education students in North- east, Nigeria. 2. Undergraduate Accounting Education students were deficient in four of the six subscales of accounting employability skills. Based on the findings, it was recommended that Accounting Educators should include the areas of deficiency in the curriculum and focus attention on developing those accounting skills identified in this study,

Keywords:Accounting skills, Accounting Employability skills, Skill Improvement Needs, Curriculum Improvement Needs
\end{abstract}

DOI: $10.7176 /$ RJFA/12-18-08

Publication date:September $30^{\text {th }} 2021$

\subsection{Introduction}

Tertiary education has over the years been recognized as a service industry, and has to tailor its curricula to meet the expectations and needs of its students and society. The National Policy on Education (FRN 2013) defines tertiary education as education given after post basic education in institutions such as Universities, Colleges of Education, Innovation Enterprise Institutes, Polytechnics and other Specialized Institution like College of Agriculture. The goals of tertiary institutions in the National Policy on Education (FRN, 2013) shall among others be to, 1) contribute to national development through high level manpower training, 2) provide accessible and affordable quality learning opportunities in response to needs and interest of Nigerians, 3) reduce skill shortages through the production of skilled manpower relevant to the needs of the labor market, and 4) promote and encourage scholarship, entrepreneurship and community service. These objectives shall be attained through the appointment and retention of professionally and academically qualified manpower: quality student intake: quality teaching and learning: adequate infrastructural facilities and services: and provision of practice oriented curriculum relevant to the needs of labor market.

Needs, according to Enemali (2010), are gaps in performance, a gap between what is and what should be. Curriculum improvements has to do with updating and incorporating new practices and technology into the curriculum in order to equip students with the skills they need for employment. It has to do with identifying the difference between optimal performance or knowledge, attitude, and skills (KAS) that an individual must have to perform certain job well and actual performance or knowledge attitude and skills possessed by an individual. According to Nora (1998) the gap between the optimal (KAS) and the actual, what an individual know or do, is the need or discrepancy. The accurate identification of the needs or discrepancy is of great value because it pinpoints specific areas where improvements are most needed (Watson, 1985).

Curriculum is the learning experiences and activities provided by educational or training institution to meet certain training or development needs (Enemali, 2010). The term curriculum refers to the knowledge, activities and the skills that the students are expected to learn, which includes the specific learning standards or objectives, 
units and lesson, assignments and projects, book, and material, used in a course; and tests, assessment and other methods used to organize and teach a particular course (Ebert, ES, Ebert, C, and Bentley; 2015).

Accounting education curriculum refers to the means and materials with which the students will interact for the purpose of learning to equip them with relevant and up-to-date skills needed to get a job or be self-employed and employ others. For example, the reviewed curricula for undergraduate degree programs of Abubakar Tafawa Balewa University, Bauchi (Department of Vocational and Technology Education (DVTE, 2016) and Modibbo Adama University of Technology, Yola ( Department of Vocational Education (2016) said accounting education is a teacher education program for preparing teachers who will be sound in pedagogy and equipped with practical accounting skills to teach in secondary schools, technical colleges, colleges of education and polytechnics as well as industrial or private sectors of the economy.

Accounting is globally useful most especially in international trade where business transactions in the world market is being recorded, analyzed and interpreted to parties concerned (Osuala, 2004). Accounting is an art of recording, classifying and summarizing in terms of money transactions. Romanus and Arowoshegbe (2014) described accounting education from two perspectives: The term accounting education "can be used to describe education for accountants ... it can also be used to describe the expansion and extension of knowledge and development of judgement of those who have already become accountants. The author added that accounting education plays an important role in obtaining a higher standard of living because it helps to identify effective and efficient use of resources. For this to occur, the training and education of accounting graduates must meet the demands and expectations of the job market. Goldstein and Gilliam (1994) reported that "when training is designed well, it gives the individual opportunities to enter the job market with needed confidence, to perform new function, and to be promoted into new situation".

Employment skills are specialized knowledge, activities and skills that are needed to get a job, help employees stay in the job, and progress to various job roles and opportunities. Zaharim as cited in Auta (2017) classified employment skills in the general area of technical vocational education and training into three areas, namely, Core Skills, Generic Skills and Personal skills. Core skills include knowledge of Science, Engineering Technology and Mathematics (STEM) and educational principles, including competencies in automobile, building, electrical/electronics, metal, wood work technology, accounting education, Agriculture education, problem solving and decision making skills. Generic skills include communication skills, computer literacy skills, goal setting skills, team work skills, self-learning skills and leadership skills. Personal attributes has to do with attributes and traits that are personal to the individual.

Chaker \& Abdullah (2011) classified the employability skills of Accountants into technical and functional, interpersonal and communication skills, and organizational and business management skills. The technical and functional skills involve financial accounting skills, management Accounting Skills, Auditing skills, Taxations and information development. The organizational and business management skills include knowledge of business environment, professional ethics and leadership development. The interpersonal and communication skills involve analytical and problem solving skills, and technological skills, According to Chaker et al, Accounting Education around the world from developing to developed world are pressured by industries and the professionals to produce graduates with relevant skills that are required at the workplace. Anonymous (2014) has suggested that a nation may embark on curriculum reform where the curriculum is felt to be outdated and out of line with emerging economic and social needs. It needs to be brought in line with ideas of modern economy.

It is in response to the need for curriculum change that the curriculum task force of the American Accounting Association (AAA) in 2010 also proposed an integrated competency based framework for Accounting Education that defines the content required for the future careers of all Accountants working in a variety of organizational settings (Lawson, et al 2014). The framework is based on the idea that Accounting Educators can better prepare students to deliver its profession's values through three levels of competencies: Accounting competencies, Foundational Competencies, and Broad Management Competencies. This paper addressed accounting employability competencies.

Accounting competencies enable accountants to integrate management and analytical methods supported by technology, to assist an enterprise to formulate and execute its strategy successfully. Accounting competencies are grouped into six categories: external reporting and analysis; planning, analysis and control; taxation compliance and planning; information system; assurance and internal controls; and professional values, ethics and attitudes (Lawson et al, 2014).

Presently, Accounting Education institutions are being expected to prepare their students to be the workforce in a globalized world, and the need for them to review their curriculum, update their teaching materials and impart knowledge and skills to students that will meet their needs cannot be overemphasized (Babajide, Samuel and Egbide, 2014). The objectives of accounting education according to Osuala (2004) are to learn how to keep better records for personal and home use; to study accounting records and reports as an integral part of the function of any business enterprise; to understand the concept of assets, liabilities and properties so that the fluctuation in business cycle may be correctly interpreted; to interpret and analyze business 
papers and records in terms of customer. The National Universities Commission, as a national quality assurance agency on university program recommended that universities should review their programs at least once in five years; and that the review should incorporate the opinions of stakeholders such as students, staff and employers (National Universities Commission, 2016).

It would appear that these objectives are not being achieved, since the current curriculum of Accounting Education is considered as not responsive to the needs of employers. For instance, Atsumbe (2009) reported that employers of labor or industries generally consider the products of vocational and technical institutions as not useable without further training and that several of the graduates roam the streets without employment as a result of lack of skills. According to Dangana (2007), "the students often find a curriculum and pedagogy that are almost devoid of content relating to work and virtue isolated from the real world of work". The author further stated that both the schools and world of work operated separately and vocational educators do not appear to be producing the well-motivated and well-rounded young people that employers would like to recruit.

Wolcot as cited in Romanus and Arewoshegbe (2014) reported that "a growing gap exists between what Accountants do and what Accounting Educators teach. Accountants who remain narrowly educated will find it more difficult to compete in an expanding profession". Garba (2013) reported that Nigerian graduates do not possess employment skills that could make them marketable in the labor market and graduate unemployment rates is increasing over the years. Sodupo (2014) stated that employers of labor often complain that some of the graduates, though professionally and technically qualified, are unemployable in that they lack the requisite essential skills or competencies needed in the job for sustainable employment.

Today, there appears to be a widening gap between the competencies needed for professional success and those taught in the universities. How should accounting education change to help close the competency gap? This has become a challenge to accounting education in its effort to prepare graduates for the world of work! The challenge centers on the emergence of the demand for changing skills set needs if accounting education is to meet the needs of employers. Employers are seeking a diverse range of skills and attributes in new accounting graduates. Birrell (2006) suggests that the managers need to take quick action to model a new accounting graduates profile with a larger range of technical and generic or employable skills.

In his welcome address at the international conference of Nigerian Vocational Association, Egbule (2016) reported that "Unemployment, especially in developing countries is likely to rise significantly if concrete measures are not put in place to improve on the current mismatch between training program and labor market and requirements and accelerate job creation". Given this trend, it has become imperative for researchers to assess the accounting curriculum content in terms of its importance for employability success of accountants; and whether or not the competencies are consciously been developed during their undergraduate studies in North- east Nigeria. Assessing the curriculum will according to Daramola (2010, p.87) ensure that "students acquire the required theoretical knowledge, desirable activities and skills in their field of specialization to meet the challenges in industries or in the world of work".

\subsection{Statement of the Problem}

There has been an increasing concern among Parents, Employers, Business leaders and Professional Experts that tertiary institutions are not adequately preparing Accounting Education graduates suitable for entry level employments in modern business environment. Prior research by (Hussein (2017), Lawan et al (2014),Babajide, Samuel and Egbide (2014), Garba (2013), Chaker and Abdullah (2011), and Atsumbe (2009) indicate that a growing gap exists between what Accountants do and what Accounting Educators teach;. In particular, Dangana (2007) reported that the students find a curriculum and pedagogy that are all most devoid of content relating to work and are separated from the real world.

Increasingly, it has been argued that technical skills should be accompanied with non-technical skills to provide accountants more flexibility, given the changing nature of global labor market. While it is widely accepted that graduates need a broad range of skill base, there is no consensus of opinion on which specific skill set should be included in the curriculum to make the graduates employable. As a step in responding to this challenge, attempt was made in this study to identify the needed improvements in undergraduate Accounting Education curriculum, as a way of closing the accounting competency gap.

\subsection{Aim of the Study}

The aim of the study was to determine curriculum content improvement needs for accounting employability skills acquisition of undergraduate accounting education students in North- east, Nigeria.

\subsection{Research Questions}

The following research questions were posed to guide the study:

1. What are the importance of the identified curriculum content improvement needs for accounting employability skills acquisition of undergraduate accounting education students in North- east, Nigeria? 
2. To what extent are the identified curriculum content improvement needs for accounting employability skills acquisition consciously developed during their undergraduate studies in North-east, Nigeria?

\subsection{Null Hypotheses}

The following null hypotheses were postulated to guide the study and were tested at 0.05 level of significance HO1: There is no statistically significant difference between the mean responses of Accounting Educators and that of Accountants in industries on curriculum content improvement needs for accounting employability skills acquisition of undergraduate Accounting Education students in North -east Nigeria

HO2: There is no statistically significant difference between the mean responses of male and that of female students on the extent to which curriculum content improvement needs for accounting employability skills acquisition of undergraduate Accounting Education students were consciously developed during their studies in North-east, Nigeria.

\subsection{Methodology}

The research design for this study is a sample survey research design. A sample survey research is a study in which a researcher infers information about characteristics of a population of interest based on the responses of a sample drawn from the population (Gay, 1996, and Osuala, 2001). In this study, attempt was made to examine areas in the specialized accounting courses that could be improved in order to make the students generally employable. The study involves the use of questionnaire to collect data from Accounting Educators, Accountants in industries and final year Accounting Education students in order to answer the research questions and test the null hypotheses related to the study. The selection of students was based on Kavanagh and Drennan (2008) justifications that they are key stakeholder group when it comes to examining views about developing skills for career in accounting profession.

The area of this study is North East region of Nigeria. The study was carried out in tertiary education institutions offering Accounting Education and industries located in North-east region of Bauchi, Gombe, Yobe, Borno, Adamawa and Taraba States. The industries used for the study were those registerable with Industrial Training Fund. The tertiary education institutions in North- east region include Abubakar Tafawa Balewa University, Bauchi, Tatari Ali Polytechnic, Bauchi, Federal College of Education Gombe, Federal College of Education, Potiskum, Modibbo Adama University, Yola, Federal College Education, Yola, University of Maiduguri, and College of Education Zing, Taraba State. The region is located between longitude $\varangle 11 \rrbracket \wedge 0$

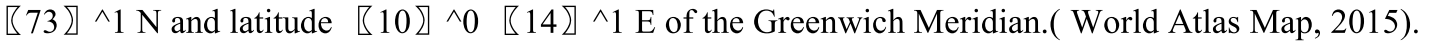

The population of this study comprised all the 172 Accountants in industries (those working as Accountants in industries and have knowledge of the required skills for employability) 52 Accounting Educators (those currently teaching Accounting Education in tertiary education) and 312 final year undergraduate Accounting Education students in North- east, Nigeria.

A total of, 281 final year undergraduate Accounting Education students and 156 Accountants in industries drawn from tertiary education institutions and industries located in North- east region of Nigeria constituted the sample for this study. This sample was selected using simple random sampling method. The sample size was randomly drawn using Krejcie and Morgan Table for determining needed sizes of randomly chosen sample(s) from a finite population (N) (Isaac and Michael, 1983). On the said Table, entries for a required sample sizes are provided in a column alongside the corresponding population of a given size. For example, a sample size of 28 students would be needed from a finite population of 30 students so that there would be a 95 percent level of confidence. There was no sampling for Accounting Educators because they are not many. The structured questionnaire developed by the researcher was used for data collection for this study. The title of the instrument is: Accounting Curriculum Content Improvement Needs for Accounting Employability Skills Acquisition (ACCINFA E S A). Three category of questionnaires were used to collect data for the study: Questionnaires for Accountants in industries with 127 items; Questionnaires for Accounting Educators with 169 items, Questionnaires for undergraduate Accounting Education students with 169 items. Two different rating scales were used for data collection for this study.

In specific term, the weight assigned to each rating scale depends on the key factors that were assessed. In general, the rating of 0 indicates complete absence of a particular quantitative indicator of the factor. The rating scale that was used to provide answers to the questions are as follows: Section A, the participants checked the options that applied to them. The questionnaire has two categories of response scales: the level of importance and the level at which the skills were developed. The importance category has a five points response scale to which the accountants in industries and accounting educators rated. The detail of the scale is as follows: $4-$ highly important, 3 - very important, 2- important, 1- some-what important, 0 - not important. The level at which the skills were developed was in the second column. In this case, the students were required to indicate their responses on the extent to which the skills listed were developed during their undergraduate studies. This was done on a five-point rating scale, ranging from $0=$ highly not developed, $1=$ not sufficiently developed, $2=$ 
developed, 3 = well developed, and 4 = highly developed. Following the above ratings, answers to the research questions one and two were obtained by finding the discrepancy between the mean level of importance and the mean level at which the skills were developed using the improvement needs index.

A team of six certified Accountants from Bauchi, two Accounting Educators, and two experts in measurement and evaluation from Abubakar Tafawa Balewa University (ATBU) Bauchi and Tatari Ali Polytechnic, Bauchi. validated the questionnaire used for data collection of this study. The experts were required to ensure that the items provide adequate answers to the research questions. They were asked to review the questionnaire in terms of clarity, appropriateness of terms, organization, expression, directions used, and correctness of spellings. In order to achieve the objectives of the study, the experts were given free hand to either remove any items they considered irrelevant or add any other items they consider important but were not reflected in the questionnaire. Based on their inputs, the questionnaire was reduced from 200 items to 169 items.

As part of the validation exercise, a pilot test was carried out in College of Education and industries located in Azare Bauchi state in order to find out the feasibility of the questionnaire for a full scale study; establish the coefficient of reliability; ensure suitability of each item for the study; and reveal deficiencies that may arise in the implementation of the design. The pilot study was carried out in Azare. Azare was selected for the Pilot Study because it has similar population characteristics with the main population of the study. The structured questionnaire used for the pilot study was administered to sample of accounting educators, final year undergraduate Accounting Education students and Accountants in industries located in Azare.by the aid of two trained research assistants. This population was not involved in the main study.

The research assistants were briefed on the purpose and participants for the study. Each copy of the questionnaire was accompanied by a letter highlighting the purpose of the study. Out of a total of 60 copies of the questionnaire distributed to accounting educators, final year undergraduate accounting education students, and accountants in industries, 51 were returned, representing 86.05 percent.

Reliability of the questionnaire is the degree of consistency with which the questionnaire measures what it intends to measure. The reliability of the questionnaire used for the study was obtained through the pilot test. Data gathered through the pilot test were analyzed using Cronbach's alpha, also referred to as coefficient alpha. Gay (1996) advised that if the items are scored such that different answers are worth different numbers of points, for examples, $0,1,2,3$, or 4, Cronbach's alpha can be used. The result showed positive overall reliability coefficient of .0 .79 for the entire questionnaire. This was considered high enough and showed that the questionnaire can be used to determine the curriculum content improvement needs for accounting employability skills acquisition of undergraduate Accounting Education students.

The structured questionnaire that was used for data collection for this study was administered to the participants by the researcher, and with the aid of trained research assistants. The research assistants were 10 in number. They were briefed on the purpose of the study and on the participants for the study. Each copy of the questionnaire was accompanied by a letter introducing the researcher and the purpose of the study. Both the research assistants and the participants were quite cooperative. The result of their efforts was high return rate and satisfactory completion of the returned copies of the questionnaire. The questionnaire was distributed and collected the following day. Out of 281 copies of questionnaire distributed to final year undergraduate Accounting Education students, 238 were returned, representing 84.69 percent return rate. Out of the 238 male and female students, females were 98 or 41.18 percent. Of the 52 copies of the questionnaire distributed to Accounting Educators, 49 or 94.23 percent were returned. A total of 121 out of 156 (represent 77.56 percent) copies of the questionnaire distributed to Accountants in industries were returned. The entire 408 copies of the returned questionnaire were used.

The data collected by the use of structured questionnaire were analyzed using frequency counts, and percentages, mean, t-test, and improvement needs index. Demographic information were collected from the participants in order to group the data for testing the hypotheses. Bartel (1976) and Morgeson (2017) advised that demographic information should be collected from the practitioners so that potential differences among demographic groups can be described.

The two research questions were analyzed using the mean, standard deviation, t-test and improvement needs index. The mean is an average score obtained to represent the views expressed by participants in a study. Sambo (2005) stated that "the mean is the most frequently used measure of central tendency and more important of all the numerical descriptive measure". The standard deviation is used to show "the degree of variation" or spread in the view of participants (Afonja, 1985). Morgeson (2017) advised that the mean, and standard deviation are typically reported for each task and also for "all the task that a particular duty comprises". Sithole (2015) showed that the "nature of the data permitted the mean and standard deviation of each skills to be calculated".

The responses of the students to the second category of response scale of the questionnaire were analyzed using improvement needs index developed by Borich (1980). The improvement needs index has been used widely to assess weighted discrepancy scores as follows: 
1. The weighted mean of each item under level of importance component $=x_{1}$

2. The weighted mean of the item under extent of competence or skill developed $=x_{d}$

3. The difference between two weighted means for each item $=x_{1}-x_{p}$

i. When the difference between the two weighted mean is zero, $(0)$ it means that improvement is not needed because the level at which the skill is needed is equal to considered level of performance of the task by accounting education students.

ii. When the difference between the two weighted mean is negative (-) for any item, it means that improvement is not needed because the level at which the skill is needed is lower than the level at which the skill is considered to be developed.

iii. When the difference between the two weighted mean is positive $(+)$ for any item, it means that improvement is needed because the level at which the skill is needed is higher than the level at which the skill was considered developed among accounting education students.

All the null hypotheses for this study were analyzed using t-test. As exposed by Isaac and Michael (1983), the t-test can be used to satisfactorily determine a significant difference between two large samples. As the basis for decision, the null hypotheses stated for the study was rejected if the probability value or value of significant level is less than or equal to 0.05 and was upheld if probability value or significant level is more than 0.05 . Data collected through the use of rating scale was interpreted relative to the real upper and the real lower limits of numbers. For the different number of points $0,1,2,3$, and 4, the real lower and the real upper limits of the numbers are as follows: 0 represents the interval between -0.50 and $0.49 ; 1$ represents the interval between 0.50 and $1.49 ; 2$ represents the interval between 1.50 and $2.49 ; 3$ represents the interval between 2.50 and 3.49 ; and 4 represents the interval between 3.50 and 4.49 . The data that were collected were analyzed using IBM SPSS version 23.

3.0 Results

Table 1: $\quad$ Analysis of Curriculum Content Improvement Needs for Accounting Employability Skills Acquisition of Undergraduate Accounting Education Students

\begin{tabular}{|c|c|c|c|c|c|c|}
\hline \multirow[t]{2}{*}{$\mathbf{S} / \mathbf{N}$} & \multirow[t]{2}{*}{ Items } & \multicolumn{4}{|c|}{$\begin{array}{c}\text { Respondents } \\
n_{E}=49, n_{I}=121, n_{S}=238, n_{T}=408\end{array}$} & \multirow[b]{2}{*}{$\bar{x}_{C}-\bar{x}_{S}$} \\
\hline & & $\bar{x}_{C}$ & $\sigma_{C}$ & $\bar{x}_{S}$ & $\sigma_{S}$ & \\
\hline & Taxation Compliance and Planning Skills & & & & & \\
\hline 1. & Understanding fundamentals of taxation & 3.21 & 0.68 & 2.75 & 0.92 & 0.46 \\
\hline 2. & Ability to calculate corporate tax & 3.25 & 0.67 & 2.58 & 0.95 & 0.67 \\
\hline 3. & Ability to calculate personal tax & 3.22 & 0.67 & 2.39 & 0.96 & 0.83 \\
\hline 4. & Ability to apply relevant tax law to work & 3.31 & 0.64 & 2.38 & 0.93 & 0.93 \\
\hline 5. & Prepare tax system & 3.26 & 0.66 & 2.37 & 1.10 & 0.89 \\
\hline \multirow[t]{2}{*}{6.} & Developing tax payment compliance program & 3.28 & 0.62 & 2.39 & 1.02 & 0.89 \\
\hline & Cluster Mean & 3.26 & 0.66 & 2.48 & 0.98 & \\
\hline
\end{tabular}

External Reporting and Analysis skills

7. Ability to explain the use of financial reports

8. Presenting financial statements to stakeholder

9. Understand generally accepted accounting principles

10. Apply relevant financial reporting standards to prepare financial statements

11. Prepare consolidated financial accounts

12. Apply international financial reporting standards in preparing financial statements

Cluster Mean

Planning, Analysis and Control skills

13. Use live data to evaluate risk

14. Know fundamental of management accounting

15. Prepare payroll

16. Apply operational planning to business

17. Prepare a budget

Cluster Mean

\subsection{8 \\ 0.65}

3.29

3.20

0.67

2.67

2.42

0.64

2.56

$3.21 \quad 0.65$

2.57

3.24

0.66

2.43

0.66

2.40

3.21

0.66

2.51

0.65
0.99

$\begin{array}{lll}1.00 & 0.51 & \text { IN } \\ 0.98 & 0.87 & \text { IN } \\ 0.95 & 0.64 & \text { IN } \\ & & \\ 0.98 & 0.64 & \text { IN } \\ & & \\ 1.00 & 0.81 & \text { IN } \\ 1.00 & 0.74 & \text { IN }\end{array}$

$\begin{array}{lll}1.00 & 0.97 & \text { IN } \\ 0.93 & 0.73 & \text { IN } \\ 0.98 & 0.88 & \text { IN } \\ 0.99 & 0.86 & \text { IN } \\ 1.03 & 0.82 & \text { IN }\end{array}$




\section{Information System skills}

18. Understand the characteristics of accounting information system

19. Apply principles of information system to business

20. Develop standards of accounting information system

21. Understand accounting internal control system issues

22. Understand accounting system design issues Cluster Mean

$\begin{array}{llllll}3.19 & 0.66 & 2.66 & 0.95 & 0.53 & \text { IN } \\ 3.24 & 0.67 & 2.54 & 0.86 & 0.7 & \text { IN } \\ 3.27 & 0.64 & 2.45 & 0.97 & 0.82 & \text { IN } \\ & & & & & \\ 3.26 & 0.65 & 2.45 & 0.93 & 0.81 & \text { IN } \\ & & & & & \\ 3.25 & 0.63 & 2.28 & 0.94 & 0.97 & \text { IN } \\ \mathbf{3 . 2 4} & \mathbf{0 . 6 5} & \mathbf{2 . 4 8} & \mathbf{0 . 9 3} & & \end{array}$

Professional Values, Ethics and Attitudes skills

23. Commitment to technical competence

IN

24. Ability to demonstrate professional judgment

26. Understanding the demands in working with

IN

\section{Cluster Mean}

0.64

\section{Assurance and Internal Control skills}

28. Know the control method used in organization

36. Understand book keeping- account receivable and payable

37. Ability to check inventory

38. Ensure smooth running of internal controls

39. Prepare invoice procedure

40. Update control procedure

\section{Cluster Mean}

3.22

3.24

3.28

3.26

3.26

3.24

3.18

3.21

3.31

\subsection{7}

0.66

2.71

0.64

0.62

0.64

0.63

0.67

0.65

0.62

3.32

3.29

3.27

3.22

3.25

\subsection{1}

0.63

0.66

0.67

0.64

3.24
2.60

2.39

2.48

2.60

2.57

2.52

2.57

2.58

2.55

2.66

2.42

2.37

2.54

\section{$\begin{array}{ll}0.65 & 2.47\end{array}$}

0.91

0.96

0.95

0.93

1.02

0.84

0.96

0.99

0.95

0.90

0.90

0.98

0.91

0.94
0.51

0.64

0.89

0.78

0.66

0.67

0.66

0.64

0.73

0.77

0.63

0.85

0.85

\section{IN}

IN

IN

IN

IN

IN

IN

IN

IN

IN

IN

IN

IN

\section{Grand Mean}

0.97

Key: $\quad \bar{x}_{C}=$ Mean of Accounting Educators and Accountants in Industries Combined, $\bar{x}_{5}=$ Mean of Students, $\sigma_{c}=$ Standard Deviation of Accounting Educators and Accountants in Industries Combined, $\sigma_{s}=$ Standard Deviation of Students, $\mathrm{n}_{\mathrm{E}}=$ number of Accounting Educators, $\mathrm{n}_{\mathrm{I}}=$ number of Accountants in Industries, $\mathrm{n}_{\mathrm{S}}=$ number of Students, $\mathrm{n}_{\mathrm{T}}=$ Total Respondents. Source: Field work, 2019

Table 1 revealed that Accounting Educators and Accountants in industries considered all the 40 accounting employability skills as very important for inclusion in the content needed for improvement of the curriculum of undergraduate Accounting Education students in North- east, Nigeria, with item mean scores ranging from $\overline{\mathrm{x}}=$ 3.15 to 3.32. The cluster mean scores for level of importance of accounting employability skills were taxation compliance and planning skills $(\overline{\mathrm{x}}=3.26)$, external reporting and analysis skills $(\overline{\mathrm{x}}=3.21)$, planning analysis and control skills $(\overline{\mathrm{x}}=3.23)$, information system skills $(\overline{\mathrm{x}}=3.24)$, professional values, ethics and attitudes skills $(\overline{\mathrm{x}}=3.26)$, assurance and internal control skills $(\overline{\mathrm{x}}=3.24)$. From Table 1, it can also be seen that undergraduate Accounting Education students in North- east, Nigeria adjudged 24 out of the 40 accounting employability skills as not sufficiently developed, with mean scores ranging from $\bar{x}=2.28-2.75$. The four cluster mean scores for extent to which accounting competencies were not developed among the students during their undergraduate studies were: Taxation compliance and planning skills $(\overline{\mathrm{x}}=2.48)$, planning analysis and control skills $(\overline{\mathrm{x}}=2.48)$, professional values, ethics and attitudes skills $(\overline{\mathrm{x}}=2.44)$, information system 
skills $(\overline{\mathrm{x}}=2.37)$.The two cluster means for which accounting competencies were developed based on their mean scores were assurance and internal control skills $(\overline{\mathrm{x}}=2.54)$. external reporting and analysis skills $(\overline{\mathrm{x}}=2.51)$, The standard deviation of accounting employability skills ranged from 0.61 to 0.70 and the cluster standard deviation was from 0.64 to 0.66. Similarly, the standard deviation of the extent to which accounting employability skills were developed ranged from 0.84 to 1.10 and the cluster standard deviation was from 0.93 to 0.99. This indicated that Accounting Educators and Accountants in industries were unanimous in their responses.

The weighted discrepancy scores $\left(\overline{\mathrm{x}}_{\mathrm{c}}-\overline{\mathrm{x}}_{\mathrm{g}}\right)$ of all the 40 accounting employability skills ranged from $\overline{\mathrm{x}}=$ 0.46 to $\overline{\mathrm{x}}=0.97$. The difference between the two weighted means is positive $(+)$. This showed that undergraduate Accounting Education students in North-east, Nigeria need improvement in accounting skills for employment success in the labor market.

Table 2: Summary of t-test Analysis of the Responses of Accounting Educators and Accountants in Industries on curriculum content improvement needs for Accounting Employability Skills Acquisition of Undergraduate Accounting Education Students.

\begin{tabular}{lcccccccc}
\hline & $\bar{x}$ & $\sigma$ & $\mathrm{N}$ & $\mathrm{Df}$ & $\alpha$ & $\mathrm{t}_{\text {cal }}$ & $p$ & Decision \\
\hline Educators & 3.37 & 0.22 & 49 & & & & & $\mathrm{~S}$ \\
Accountants & 3.19 & 0.17 & 121 & & & & & \\
\hline
\end{tabular}

KEY: $\quad \bar{x}=$ Mean, $\sigma=$ Standard Deviation, $\mathrm{n}=$ Number of Respondents, $\mathrm{df}=$ Degree of Freedom, $\alpha=$ level of significance, $\mathrm{t}_{\mathrm{cal}}=$ Calculated $\mathrm{t}$-value, $p=$ Significance (2-tailed), $\mathrm{NS}=$ not significant, $\mathrm{S}=$ significant. Source: Field work, 2019

Table 2 showed the summary of t-test comparison of mean responses of Accounting Educators and Accountants in industries relating to curriculum content improvement needs for accounting employability skills acquisition of undergraduate Accounting Education students in North-east, Nigeria. The said Table indicates that the $\mathrm{t}$-value $(\mathrm{t}=5.91, \mathrm{df}=168, \mathrm{P}<0.05)$ was statistically significant. Consequently, the null hypothesis 1 was rejected. This implies that Accounting Educators and Accountants in industries shared different opinions concerning the curriculum content improvement needs for accounting employability skills acquisition of undergraduate Accounting Education students in North-east, Nigeria.

Table 3: Summary of t-test Analysis of the Responses of Male and Female Students on Extent of Development of Accounting Employability Skills Acquisition of Undergraduate Accounting Education Students.

\begin{tabular}{lcccccccc}
\hline & $\bar{x}$ & $\sigma$ & $\mathrm{N}$ & $\mathrm{Df}$ & $\alpha$ & $\mathrm{t}_{\text {cal }}$ & $p$ & Decision \\
\hline Male & 2.55 & 0.33 & 140 & & & & & $\mathrm{~S}$ \\
Female & 2.39 & 0.33 & 98 & & & & & \\
\end{tabular}

KEY: $\quad \bar{x}=$ Mean, $\sigma=$ Standard Deviation, $\mathrm{n}=$ Number of Respondents, $\mathrm{df}=$ Degree of Freedom, $\alpha=$ level of significance, $\mathrm{t}_{\text {cal }}=$ Calculated t-value, $p=$ Significance $(2$-tailed), NS $=$ not significant, $\mathrm{S}=$ significant. Source: Field work, 2019

Table 3 revealed the summary of t-test comparison of the mean responses of male and that of female students relating to curriculum content improvement needs for accounting employability skills acquisition of undergraduate Accounting Education students in North-east, Nigeria. The said Table shows that the $t$-value $(\mathrm{t}=$ $3.60, \mathrm{df}=236, \mathrm{P}<0.05)$ was statistically significant. Therefore, the null hypothesis 2 was rejected. This implies that male and female students in this study shared different opinions relating to extent of development of curriculum content improvement needs for accounting employability skills acquisition of undergraduate Accounting Education students in North-east Nigeria.

\subsection{Summary of findings}

This sub-section presents the findings of the study. The presentation was guided by the research questions explored in the study and the null hypotheses.

1. The Accounting Educators and Accountants in industries reported that all the listed accounting employability skills as very important for inclusion in the curriculum content needed for improvement of undergraduate Accounting Education students in North-east, Nigeria: Accounting education students accepted four of the six clusters of accounting employability skills as not sufficiently developed during their undergraduate studies, except external reporting and analysis, assurance and internal control that were considered as developed. The weighted discrepancy mean scores for level of importance by 
accounting educators and accountants in industries are higher than the weighted discrepancy mean scores for level of development by undergraduate Accounting Education students in all the listed skills. Since the difference between the two weighted mean scores $\left(\bar{x}_{\mathrm{c}}-\bar{x}_{\mathrm{g}}\right)$ is positive, there is the need for improvement in specialized accounting content of the curriculum of undergraduate Accounting Education students to enable them succeed in their jobs.

2. Both Accounting Educators and Accountants in industries for this study shared different views on level of importance of accounting employability skills that should be included in the curriculum of undergraduate Accounting Education students in North-east, Nigeria.

3. There is a statistically significant difference between the mean responses of male and that of female undergraduate Accounting Education students on the extent to which accounting employability skills were developed during their undergraduate studies in North-east, Nigeria.

\subsection{Discussion of Findings}

Research questions one and two sought to identify curriculum content improvement needs for accounting employability skills acquisition of undergraduate Accounting Education students and the extent to which the skills were consciously developed during their undergraduate studies in North- east, Nigeria. The response to these research questions are summarized in Table 1. The result obtained from these research questions showed that Accounting Educators and Accountant in industries adjudged all the 40 accounting employability skills as very important for inclusion in the curriculum of undergraduate Accounting Education students in North- east, Nigeria. Each of the items had mean values ranging between $x^{-}=3.14$ and 3.32 and cluster mean values between $x^{-}=3.21$ to 3.26. Analyses of the results on Table 1 showed that the cluster mean values are taxation compliance and planning skills $\left(\mathrm{x}^{-}=3.26\right)$, professional values, ethics and attitudes $\left(\mathrm{x}^{-}=3.26\right)$, assurance and internal control skills $\left(\mathrm{x}^{-}=3.25\right)$, information system skills $\left(\mathrm{x}^{-}=3.24\right)$, planning analysis and control skills $\left(\mathrm{x}^{-}=3.23\right)$, external reporting and control skills $\left(\mathrm{x}^{-}=3.21\right)$.

The overwhelming acceptance of the accounting employability skills by Accounting Educators and Accountants in industries is consistent with Lawan et al (2014) who reported the American Accounting Association proposal that Accounting Education students need the listed accounting employability skills in order to prepare them adequately to face the turbulent global environment of the future. Based on the cluster mean values as indicated on Table 1, undergraduate Accounting Education students considered taxation compliance and planning skills $\left(\mathrm{x}^{-}=2.48\right)$, planning analysis and control skills $\left(\mathrm{A}^{-}=2.37\right)$, information system skills $\left(\mathrm{x}^{-}=2.48\right)$, professional values, ethics and attitudes $\left(\mathrm{x}^{-}=2.44\right)$ as not sufficiently developed during their studies. Further analysis of the results on Table 1 showed that external reporting and analysis $\left(\mathrm{x}^{-}=2.51\right)$, assurance and internal control $\left(\mathrm{x}^{-}=2.54\right)$ were adjudged by undergraduate accounting education students as consciously developed during their studies. It was determined from the study that since the difference between the mean levels of importance are higher than the mean levels of development for all the items, undergraduate Accounting Education students need varying levels of improvement in four of the six accounting employability skills in which they are deficient.

The result that undergraduate accounting education students are deficient in four cluster of the accounting employability skills correspond with that of Nwokoye and Okeke (2016), Azunku et al (2016), Sithole (2015), Klibi and Oussi (2013), Chaker and Abdullah (2011) who in their respective studies reported that employers are seeking a diverse range of technical and foundational skills to be incorporated into existing Accounting Education curriculum to provide reasonable assurance that accounting graduates will be able to work successfully across a wide spectrum of organizations and advance in their careers. The result is not coming as a surprise because according to Romanus and Arowoshegbe (2014), the program of Accounting Education must provide products who have acquired broad array of skills and the curriculum must be structured to emphasize broad skills. Musou (2017) reported that education reform is needed in accounting in order to make the advanced professional ideal explicably recognized and more consciously cultivated in the school setting. Babajide, Samuel and Egbide (2014) has shown that in order for Accountants to maintain relevance, it has to keep evolving with the changing environment.

The findings concerning the null hypothesis number one showed that, with $p$-value of 0.00 which is less than 0.05 on Table 2 , the null hypothesis that there is statistically significant difference in the mean responses of Accounting Educators and Accountants in industries on accounting employability skills needs of undergraduate Accounting Education students is rejected. This finding is similar to that of Sithole (2017) who established that there is significant difference in mean gap between accounting skills that is demonstrated and accounting skills that is needed for 15 items of the study.

The findings related to hypothesis two showed that with the P-value of 0.00 which is less than 0.05 in Table 3 , the null hypothesis that there is no statistically significant difference between the mean responses of male and that of female undergraduate Accounting Education students on the extent to which accounting employability 
skills were developed during their studies was rejected. Further analysis of the results contained in Table 3 showed that female participants rated accounting employability skills lower than the male. This result is at variance with that of Tibi, Olueh, and Kifordi (2016) who established that female participants rated job creation opportunities in youths agricultural entrepreneurial program and skill training entrepreneurship scheme higher than male participants.

In a summary, the finding of this study indicated that undergraduate accounting education students need improvement in accounting competencies identified in this study. It was found in this study that Accounting Education students perceive themselves as deficient in most of the skills that were considered as very important for them to secure relevant place in the labor market. The study has clearly shown that female undergraduate Accounting Education students were less confident about their capabilities than their male counterpart.

This perception of their abilities may be explained in terms of their sex role after graduation. The female students may probably have believed that they will get married and the responsibility for their up keep will be on their husbands. A further possible explanation for the findings could be that the instructional skills that the teachers use in preparing the students may not be in keeping with their demands, interest and values.

It can also be seen that Accounting Educators rated all the skills lower than the accountants in industries. The overwhelming acceptance of the proposed skills by Accountants in industries may be an indication of their desirability by employers of labor. This may suggest the need for review of the undergraduate curriculum of Accounting Education that will provide broad based education towards meeting the emerging needs of employers and new accounting education graduates.

\subsection{Conclusion}

Accounting Education graduates like other graduates need to have the required skills that would enable them secure and succeed in relevant place in the labor market. As a result of a series of high profile corporate failures, change of technology and globalization of world economy, employers are seeking a diverse range of skills and attributes in graduates in order to maintain a competitive advantage. Today there is the question as to which specific skill set should be included in the undergraduate curriculum of Accounting Education students to make them employable. This study is part of the effort to respond to the challenges by identifying areas of undergraduate accounting education curriculum in which improvements are needed in the training of Accounting Education students. Based on the research focus of this study, it was discovered that undergraduate Accounting Education students are deficient in the areas of taxation compliance and planning skills, planning analysis and control skills professional values, ethics and attitude skills. This situation requires a review of the accounting component of undergraduate curriculum for Accounting Education to capture the areas of deficiency identified in this study, so that the products will be equipped with relevant skills, knowledge and attributes that will meet the imperative needs of employers and students,

\subsection{Recommendation}

Accounting educators should intensify efforts to include taxation compliance and planning skills, planning analysis and control skills, professional values, information system, ethics and attitudes skills in the curriculum of undergraduate accounting education students. These skills are needed to improve employability of the students and to assist their future enterprises to formulate and execute its policies and strategies.

\section{References}

Afonja, B. (1958). Introductory Statistics: A learner's motivated approach: Evans Brothers (Nigeria Publishers) Limited.

Anonymous, (2014). Curriculum development. http://europa.eu/capacity4dev/file/23136/ download/

Atsumbe, B.N. (2009). School industry partnership: A veritable tool for quality technology education. Journal of Curriculum and Teaching 1(2), 38-49.

Atsumbe, B.N. Okoro, O.M. and Ogwo, B.A. (2012). Improvement needs of theoretical content of technical college mechanical engineering craft practice curriculum in Nigeria. International Journal of Research in Engineering, IT and Social Sciences. 2(5), 77-91.

Atsumbe, B.N. Okoro, O.M. and Ogwo, B.A. (2012). Practical skill empowerment needs of technical college mechanical engineering craft practice curriculum in Nigeria. Journal of education and vocational research. 3(4), 118-126.

Auta, M.A. (2017). Adequacy of technology education programmes in Nigerian Universities in preparing students for the acquisition of requisite employment skills. Unpublished M.Tech (Ed.) Thesis. Modibbo Adama University of Technology, Minna.

Azunku, F.N. Nwarieji, F. and Omaru, U.A. (2016). Areas of modification in the training of students, teachers of agriculture in colleges of education for job creation in South East Nigeria, Journal of Association of Vocational and Technical Educators of Nigeria. 21(1) 154-161. 
Babajide, O., Samuel, F., and Egbide, B., (2014). Curriculum for accounting education in Nigeria. British Journal of Education, Society and Behavioural science. 4(12), 1762-1774. Retrieved from http://www.researchgate.net/publication.

Bartel, C.R. (1976). Instructional analysis and materials development: American Technical Publishers Inc.

Birrel, B., (2006). The challenges facing the accounting profession in Australian. CPA, Melborne.

Borich, G.D. (2002). A need assessment model for conducting follow-up studies. The Journal of Teacher Education. 31(3), 39-42.

Business Dictionary. (2015). Definition. Retrieved from: http://www.business dictionary.com

Chaker, M.N., and Abdullah, T.A.T. (2011). What accounting skills are required at college? International Journal of Business and Social sciences. 2(18), 193-199. Retrieved from: http://www.ijbssnet.com/journals/vol-2-no-18-october-2011/24.pdf.

Dangana, D.M. (2007). Employer's expectation of graduates of vocational technical education in Nigeria. The Journal of Nigerian Association f Teachers of Technology. 6(2)103-115.

Daramola, I.S. (2010). Strengthening technology education curriculum as a tool for re-branding Nigeria. Sahel Journal of Teacher Education 2(2), 85-87.

Department of Industrial and Technology Education (2016). Submission of Modibbo Adama University of Technology to National University commission self-study form for Accreditation.

Department of Vocational and Technology Education (DVTE, 2016). Reviewed curricula for Bachelor of Technology Degree. Abubakar Tafawa Balewa University, Bauchi.

Downie, N.J and Health, R.W. (1974). Basic statistical methods: Harper and Row Publishers.

Ebert E.S., Ebert, C., and Beautley, M.L., (2015). Curriculum definition. Retrieved from http://www.education.com/reference/article/curriculumdefinition.

Egbule, P.E. (2016). Welcome address by the National President, Nigeria Vocational Association (NVA) at the opening ceremony of the $24^{\text {th }}$ International Conference of the Association holding on $9^{\text {th }}$ June, at the ICT Complex, Taraba State University, Jalingo. Pp.11-12. Book of Abstract and program.

Enemali, J.D. (2010). Education and Training for Industrialization: Sterling Horden Publishers Ltd.

Federal Republic of Nigeria, (FRN, 2013). National policy on education, $6^{\text {th }}$ Edition: NERDC Press.

Garba, Y.E. (2013). Relationship between pre-service technical teacher training in Colleges of Education and Job performance of technical teachers in Northern Nigeria. Unpublished Ph.D Thesis, Modibbo Adama University of Technology, Minna.

Gay, L.R. (1996). Educational research competencies for analysis and application. (5 ${ }^{\text {th }}$ edition) Merril an imprint of Prentice Hall.

Hussein, A. (2017). Importance of generic skills in accounting education: Evidence from Egypt. International Journal of Accounting and Financial Reporting. 7(2), 16-35. Retrieved from DOI:10.5296/ijafr.v7i2/11782.

Idris, S.O. (2017). Work skills improvement needs of graduates of Technical colleges in building construction and maintenance for employment in contemporary. Nigeria Journal of Nigeria Association of Teachers of Technology. 12(3), 51-59.

Isaac, S. and Micheal, W.B. (1983). Handbook in research and evaluation for education and behavioral sciences: Edits Publishers.

Jat, R.B. and Jugu, Y.G. (2008). Modern financial accounting: Theory and Practice: Ehindero Nigeria Ltd.

Kannaiah, D. and Kumar, N.S. (An Urgent need for ethics for accountants). Issues I Social and Environmental Accounting. 3(1). 88-94. Retrieved from http://researchonline.jcu.edu.au /28964/1/Ethics-Edn.pdf.

Kavanagh, M.H. \& Drennan, L. (2008). What skills and attributes does an accounting graduate need? Evidence from student perception and employer expectations. Accounting and Finance. 48(2) 279-300.

Klibi, M.F. and Oussii, (2013). Skills and attributes needed for success in accounting career: Do employers expectation fit with students' perceptions? International Journal of Business and Management. Retrieved from: http://www.ccsenet.org/journal/index.php/ijbm/article/ download/24005/15973 and Sa=U and V ed $=$ 2 .

Lawson, R.A., Blocher, E.J., Brewer, P.C., Cokins, G., Sorenson J.E., Stout, D.E., Sundem, G.L., Wolcot, S.K., \& Wouters, M. J. F. (2014). Issues in accounting education. American Accounting Association. 29 (2), $295-$ 317 DOI: 102308/iace-50673.

Moisescu, F. (2016). Accounting ethics and social responsibility in a knowledge based economy. The European proceedings of social and behavioural sciences. Retrieved from: http://www.future-academy-orguk/files/images/upload/WLC2016FAO77F.pdf

Morgeson, F. P. (2017). Job analysis method. SAGE Publication, Inc.http://msu.edu/morgedon/2017b.pdf. DOI: $\mathrm{http} / / \mathrm{dx}$.doi.org/10.4135/9781483386874n254.

Musov, M. (2017). It does not matter how we assess the competencies in accounting education. Economic Alternative. 3, 429 - $448 \mathrm{http}$ //www.unwe.lg/uploads/alternatives/8-Alternative-en-3-2017.pdf.

National University Commission (2016). Benchmark for undergraduate degrees in Nigeria 
Naido, J., Jackling, B., Oliver, B. and Prokofieva, M. (n.d.) Identifying the employment-expectation performance gaps of early career accounting graduates. Retrieved from: http://mams.rmit.edu.au/ztct5ymtloht.pdf.

Nora, R. T. (1998). Rossett on TNA. In P. J. Dean D. E. Repley (eds). Performance improvement interventions, instructional design and training methods for organizational learning. International Society for Performance Improvement.

Nwokike, F. O., and Okoli, B. E. (2015). Improving the quality and relevance of business education programme through collaboration with corporate sector. Nigeria Vocational Association Journal. 20(1), 322 - 331.

Nwokoye, C. F. Okeke, D. O. (2016). Work skill improvement needs of women farmers in bitter leaf production for job creation and national development in Anambra development in Anambra State. Journal of Association of Vocational and Technical Educators of Nigeria. 21(1), 27 - 36.

Osuala, E. C. (2004). Business management, Cape Publishers International Limited.

Osuala, E. C., (2001). Introduction to research methodology, Africana FEP Publishers Limited.

Romanus, O. O. \& Arowoshegbe, A. (2014). The challenges of accounting education. The Nigerian Experience. Accounting and Finance Research, 3(2), 129 - 137.

Roy, R. H., Macneil, J. H. (2009). Communication of the ACM. Journal of Business Communication. 7(4) 39 44.

Russell, B. (2010). Revenue administration: Developing a taxpayer compliance programme. Technical notes and manuals: International monetary fund. Retrieved from: http://www.imf.org/external/pubs/it/tnm/2010/tnm.1017.pdf

Sacer, I. M. and Oluic, A. (2013). JIOS. 37 (2), 117-126. Retrieved from: http://hrcak.srce.hr/file/164977.

Sambo, A. A. (2005). Research Methods in Education, Stirling-Horden Publishers (Nig) Ltd.

Shanker, S. (n.d). The advantages of using an accounting software package for invoice. Retrieved from: $\mathrm{http}: / /$ smallbusiness.chrom.com/advantages-using-accounting.software

Sithole, S. T. M. (2015). Quality in accounting graduates: Employer expectation of the graduates skills in the Bachelor of accounting degree. European Scientific Journal 11(22). 165 - 180. Retrieved from: https//eujournal.org/index.php/esj/article/viewfile/6052/582a8ved=zahukewiq80bh35vyahwezaQKHTescpy qfjaeegqfr

Sodupo, O.O. (2014). Employability of Tertiary education graduates in Nigeria: Closing Gap. Global journal of Human Resource Management 2(13), 28-36

Tibi, E. U., Olueh, C.E and Kitordu, A.U (2016). Perception of youth agricultural entrepreneurs programme and skill training entrepreneurship programme for job creation by unemployed youths in Delta State. Journal of Association of Vocational and Technical Educators and Technical Educators in Nigeria. 21(1)126-135.

Watson, C. E. (1985). Management development through training, Adlivon-Wesley Publishing Company. Inc.

World Atlas Map (2015). Flags, and facts of every Country. http// www.worldatlas.com/ 